\title{
GOUVERNEUR CANTZ'LAAR EN DE BLOEDIGE GEBEURTENIS VAN 1 JUNI 1824 \\ DOOR
}

\section{MR. B. DE GAAY FORTMAN}

De verwijten, die Simons en Brusse in hun geschiedbeschrijvingen van Curaçao aan den gouverneur Cantz'laar doen, zijn, voorzoover zij de dubloenenzaak en het verzet der schutterij op 1 Augustus 1821 betreffen, overdreven. Ernstiger is het, wanneer Dahlhaus zich bij hen schijnt aan te sluiten, en met hen dien gouverneur aansprakelijk stelt voor de ernstige gebeurtenis van 1 Juni 1824, die een waarschijnlijk onschuldig slachtoffer eischte ${ }^{1}$ ). Deze beschuldiging is ten eenenmale ongegrond. Een onderzoek dat zich verder uitstrekt dan de bronnen, waarover Dahlhaus de beschikking had, toont dit onweerlegbaar aan.

Het verhaal van Brusse en Simons komt hierop neer: De priester Joachim doopte niettegenstaande het verbod een Jood (Joseph Alvares Correa), waarop de gouverneur door zijn adjudant, nadat Joachim aan de gerechtsdienaars geweigerd had, dit te doen, last gaf, de kerk te sluiten. De pastoor en vele leden zijner gemeente, die zich in de pastorie en op het plein om de kerk bevonden, boden hevigen tegenstand. Een militair detachement maakte zich meester van het binnenplein en loste eenige schoten, welk voorbeeld gevolgd werd door eenige agenten, waardoor een zekere Theodorus Lesire het leven verloor.

Wat zeggen hiervan nu de authentieke stukken?

De fiskaal had - zooals hij zelf aan den gouverneur schreef; door familieleden van Correa onderricht ${ }^{2}$ ) - het

1) Simons, Beschrijving van het eiland Curaçao; Brusse, Curaçao en zijne bewoners; Dahlhaus, Een levensschets (van Msg. Niewindt).

2) O u d-a r c h i e f, no. 314 . 
noodig geoordeeld, 28 Mei 1824 „Aan den Roomsch Catholyke Geestelyke, alhier dienst doende" schriftelijk te verzoeken, om, in afwachting van de komst van den door den Koning benoemden pastoor en kapelaan „, tot voorkoming van alle wanorders en combustien geen andere dienst te verrigten als die nodig is tot stigting en behering dezer herderlose gemeente, en mitsdien dezelve by de tegenwoordige individuele leden der Kerk, en haare kinderen, in het doopen en toedienen der verdere Sacramenten, en alle verdere geestelyke vertroostingen te bepalen" ${ }^{1}$ ).

De la Olleria, zoo heette de priester, antwoordde den 31 sten Mei met den volgenden brief volgens de in niet onberispelijk Hollandsch gestelde vertaling uit het Spaansch van den gouvernementstolk Ricardo.

"Op zyn tyd heb ik de geeerde missive van UwelEdele Gestrenge in dato 26: dezer ontvangen, waarin het U behaagd my te zeggen, dat er zich geen zwarigheid op doende ten einde, ik, als Pastoor van dezen geheiligde katolieksche kerk, in alle de uitoeffeningen myner ministerie voortvare, my alleenlyk aanzegt, om het Sacrament van den Doop aan den Iood en geloofs onderwyzeling Ioseph Alvares Correa die daar met de grootste waarheid naar haakt te suspendeeren.

In antwoord moet ik aan UwelEdele Gestrenge, met alle de eerbied, aan Uwen waardigheid Competerende, onder het oog brengen, dat ik in de post van Pastoor van de katolieksche zielen in deze heiligen kerk gecongregeerd, op den 16e November des voorledene Iaar getreden ben, door delegatie of magt van myn voorganger de Eerwaarde Vader kloosterling Pedro Hernandez. dat van deze delegatie en benoeming kennis is gegeven geworden door de kerkmeesters van gemelde heiligen kerk aan Zyne Excellentie den Heer Gouverneur van dit Eiland, en dat op het verkrygen van zyne goedkeuring deswegens, volgens Missive de dato 6 November 1823 N. 737. bezit genomen heb van myne Pastoralen ambt dewelke ik thans beklee, opvolgende de pligten derzelven volgens de Roomsche Ritis [ritus], zonder eenige de minste tegenspraak.

Ik kan in myne Ministerie in niets, in gebreken blyven aan de precepten van onzen heilige katolieksche Godsdienst; Eene der voornaamste en door dezelve aanbevolen, bestaat, in de Administratie van het Sacrament van den Doop van geloofs onderwyzelingen die zulks, (zooals den bedoelde perzoon) op eene behoorlyke wyze soliciteren, zonder dat ik uit aanzien van iemand hoegenaamd zulks kan uitstellen van het ogenblik af, dat ik den solicitant daartoe bevoegd acht, gelyk de tegenswoordige aspirant zulks reeds is, als wanneer het mynen pligt is hem dezelve dadelyk te administreeren, om aan de heiligen wet welke my zulks gebied te voldoen, zonder bezorgd te zyn dat in myn kerk eenige beweging zoude kunnen plaats nemen strekkende tot belemmering of beletzel in myne functien, schoon het uit de Missive van UwelEdele Gestrenge blykt dat UwelEdele Gestrenge eenige populaire commotie vooruit ziet. En daar de katolieksche Religie

1) O u d-a r c h i e f, nrs. 314 en 717. 
publiek op dit Eiland is, zal tot de waakzaamheid van UwelEdele Gestrenge behoren, zoodanige mesuren te nemen, als nodig zullen worden geoordeeld om welke wanorde het ook zy voor te komen - hetwelk ik ter kennisse van UwelEdele Gestrenge breng, verzoekende gelyk ik UwelEdele Gestrenge mits deze, met verschuldigde eerbied opregtheid en goede trouw verzoek, de goedheid te willen hebben van my te Excuseeren dat ik niet instemmen kan in de bemiddeling voorgesteld in UwelEdele Gestrenge geEerde missive; UwelEdele Gestrenge verzekerende in allen waarheid dat in welke andere zaak ook, waarin UwelEdele Gestrenge zich zal vervaardigen van my te occuperen, ik de grootste genoegen zal hebben om Uwen voorschriften te gehoorzamen en op te volgen.

De Here behoude UwelEdele Gestrenge voor veele Iaren."

Dit antwoord bracht den fiskaal tot een nieuwen brief, ? op 1 Mei, die 's middags om half twee, aan den geestelijke werd verzonden, waarin de fiskaal meedeelde, dat hij zich verplicht had gezien, diens brief ter kennis van den gouverneur te brengen ${ }^{\mathbf{1}}$ ), „Uweerw: by deze inviterende en desnoods op Uweerw ${ }^{\mathbf{B}}$ verandwoordelykheid gelastende, met de bewuste toediening der doop niet voortegaan, voor dat Zyn Excellenties intentie deswegens en tenregarde van het regt in 't algemeen aan de Roomsch Catholyke Geestelyke thans zich hier te lande bevindende, ten opzigte hunner geestelyke functie al of niet toegekent, zal kenbaar geworden zijn ${ }^{2}$ )". - Bovendien verzocht de fiskaal den kerkmeester De Graaff „deze openbare doopsbediening te doen voorkomen en daarmede te supercederen tot de aankomst van de door Zijne Majesteit aangestelde Pastor en Kapelaan uit het Moederland, waarin geheel en al condecendeerde", zooals in den brief van 1 Juni 1824 aan den gouverneur te lezen is. Volgens mededeeling van den substituut-schout zou De la Olleria ${ }^{3}$ ) terstond na ontvangst van dezen brief met gesloten deuren de doopsbediening hebben doen plaats vinden ${ }^{4}$ ).

Men zal in dezen tijd niet anders zeggen, dan dat het recht aan de zijde van den priester was, dat zijn brief

$\left.{ }^{1}\right)$ Dit deed hij echter eerst den volgenden dag.

2) O u d-a rchief, no. 314 en 717. Het is dus niet juist om zonder meer te zeggen, zooals Niewindt doet in zijn brief, waarin hij van deze gebeurtenis verslag geeft, dat de pastoor van den fiskaal bevel ontving, om den Jood niet te doopen. Dahlhaus, t.a.p., bladz. 51. Niewindt had zijn inlichtingen weer van derden.

s) De fiskaal noemt hem hier: Eleria.

4) O u d-a rchief no. 717. 
aan den fiskaal waardig was, en ook dat hij op zijn standpunt volkomen gelijk had niet met te voldoen aan de laatste ,invitatie” van dien ambtenaar. Als De la Olleria werkelijk van plan is geweest de doopsbediening in het openbaar te doen plaats vinden, dan is het reeds als een toegeven van hem te beschouwen, dat hij deze ten slotte „met gesloten deuren” deed.

Op welk standpunt de fiskaal rechtens stond, blijkt uit dit gedeelte van zijn brief van 1 Juni aan den gouverneur, waarin hij meedeeling deed van het gebeurde :

„Hoezeer ik zeer wel weete dat de placaten van H.H.M. tegens de roomsche Geestelyken, monniken, nonnen, quesels en diergelijken, welke ook eenmaal alhier in observantie geweest zyn, na den jaare 1795, en speciaal na de aangenomene grondwet, moeten gerekent worden in genere vervallen te zyn, en art. 20 van 't Reglement op de regering dezer Kolonie, zulks ook schijnt te denoteren, is het evenwel niet tegen te spreken dat de situatie der Roomsch Catholyke gemeente op dit Eiland, en de staat der veelen haarer leden een meerdere en zelf uitgestrekte surveillance, over het gedrag der Geestelyken, vooral van vreemde zich hier ophoudende noodzakelyk maakt, die ligtelyk op een gelyk fundament als by deze missive van de kloosterling sub B ten regarde van zogenaamde Geestelyke verpligtingen gelegt, opinien zoude kunnen propageren nadelig voor de rust en goede order, indien hierin niet by tyds kragtdadig worde voorzien.

Uw Excellentie gelieve volgens hoogst deszelfs meer verligt oordeel te decideren of en in hoe verre de zin en mening, in de toelating van 30 Mey 1822, door deze proselyt making is geusurpeerd, en deze kloosterling Joaquin de la Jlleria hierover en meer speciaal noch over de non obtenperantie aan de hem door het officie fiscaal toegezondene surcherende bevelen, by missive van 31 Mey 11 . vermeld correctie is meriterende al dan niet."

Heel sterk lijkt dit standpunt niet. Niettemin deelde de gouverneur het, die blijkens aanteekening in zijn journaal het gedrag van den priester onbestaanbaar noemde met de goede orde en handhaving der politie, en den Room- 
schen geestelijke verklaarde, „gesuspendeerd .... met insinuatie aan de kerkmeesters .... om niet te gedogen, dat die geestelijke of eenige andere, door ons niet geadmitteerd zijnde, eenige priesterlijke functien bij hunne gemeente waarneme." Tegelijkertijd werd den fiskaal verzocht te overwegen, of er termen waren tegen den priester te procedeeren, en indien niet, daarvan kennis te geven aan den gouverneur, die dan zou doen, wat hij dienstig en raadzaam zou oordeelen „voor de rust en goede orde en tot handhaving van het gezag der politie”. 1)

Men ziet, dat in deze beschikking van den gouverneur met geen woord sprake is van een last om de kerk te sluiten, zooals Niewindt den gouverneur in de pen geeft ${ }^{2}$ ), en ook Simons en Brusse hem verwijten. En met de laatsten zijn de officieele bronnen het eens, dat juist de uitvoering van dezen maatregel der kerkmeesters de oorzaak van de wanordelijkheden van dien avond met haar noodlottige gevolgen geweest is. Ookals men den brief leest, door Dahlhaus afgedrukt, van de kerkmeesters De Graaf en Monsanto aan De la Olleria ${ }^{3}$ ), ziet men daarin duidelijk staan, dat de gouverneur hun meegedeeld heeft, den priester geschorst te hebben en hen verplicht te hebben, niet te veroorloven, dat De la Olleria noch een der andere geestelijken, niet geadmitteerd zijnde, ${ }^{4}$ ) de geestelijke diensten van den godsdienst uitoefene. Daaraan verbinden kerkmeesters het verzoek aan den pastoor om de pastorie te verlaten, de kerk te sluiten en hun de sleutels te sturen ${ }^{5}$ ).

1) O u d-a r c h i e f no. 241. Vreemd genoeg komt de brief zelf niet voor in het register van uitgaande civiele binnenlandsche stukken, O u da r chief no. 362 .

2) Dahlhaus, t. a. p., bladz. 51 .

s) T. a. p., bldz. 52 .

4) Het is onbegrijpelijk, dat Dahlhaus deze laatste drie woorden uit de Nederlandsche vertaling weglaat, daar ze vlak daarboven in het Spaansch "no siendo admitido por su Excellencia" wel staan. Deze woorden zijn daarom van zooveel beteekenis, omdat, zooals nog nader blijken zal, de gouverneur niet beter wist, of er was nog een priester, Nicholas Antonio Diaz, 13 Mei 1822 als tweede pastoor toegelaten. Zie Dahlhaus, t. a. p., bladz. 41, die het heengaan van Diaz ook niet vermeldt. Er was dus geen reden om de kerk te sluiten.

s) Deze brief is overgebracht door den aanspreker Laurent Delatry, die 
Omtrent de verdere gebeurtenissen verhaalt de fiskaal in een brief van 3 Juni aan den gouverneur, dat De Graaff zich in den middag van den 1sten bij hem had gevoegd, meldende van den gouverneur order te hebben ontvangen, dat „de bekende Geestelyke .... de kerk en pastory moest verlaten”, en zich beklagende, dat „men hem nu reeds van alles de schuld gaf", waardoor hij voor zijn persoon onaangenaamheden vreesde. Later op den dag was De Graaff bij den fiskaal op last van den gouverneur, voor het geval van verzet bij de uitvoering van des gouverneurs bevelen, zooals hij zeide, hulp komen vragen, waarop de fiskaal den schout en twee onderagenten had gelast zich ter beschikking van den kerkmeester te stellen die ook nog gezegd had, dat de pastoor binnen één uur de pastorie moest ontruimen.

Eerst kreeg de fiskaal toen rapport, „dat de pastoor gewillig was de pastory te verlaten, dan zeer kort daarop

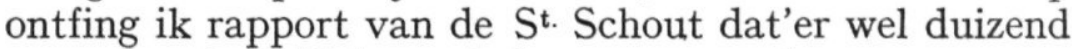
menschen inmiddels op de been waren gekomen, en men de kerk niet naderen konde; en alles een oproerig aanzien verkreeg, zo dat ik dadelyk daarvan kennis deed geven aan de Hoofdwagt, waarvan dan ook een detachement na de overzijde gemarcheert is", dat volgens mededeeling van kapitein Dietz op last van den gouverneur had gereed gestaan. Om twee uur 's nachts was het lijk van Lesire op het fiskalaat gebracht ${ }^{\mathbf{1}}$ ).

Van meer belang is het verslag van den substituutschout Dittinger van 2 Juni, dat bij den brief aan den gouverneur in afschrift gevoegd is:

„Ik ondergeteekende St. Schout verklare by deze op den eed aan den lande gedaan. -

Dat ik gisteren omstreeks half zeven uur des avonds gelast werd door den WelEdele Gestr. Heer Raad fiscaal om my met de politie bedienden naar de Overzyde te begeven, ten einde aldaar, des nodig zynde, de kerkeraden van de Roomsch Catholyke gemeente de behulpzame hand te verlenen tot afweren van oploop als anderszins. -

Dat ik my vervoegt hebbende by den Heer D. De Graaff zynde eene der kerkeraden hem de my gegeven last bekend maakte, die my te kennen gaf,

daarover veel te verduren heeft gehad van de bevolking. Zie Koloniaal Weekblad 11 Febr. 1926.

$\left.{ }^{1}\right)$ O u d-a r c h i e f, nrs. 314 en 717. 
dat de Pastoor niet te huis zijnde, hy aan den Persoon van L. Latrie order gegeven had, om binnen de tyd van een uur de sleutel van de Pastory by hem te bezorgen, en dat de Priester dezelve binnen dien tyd moest ontruimen. -

Dat terwyl ik aldaar eenigen tyd vertoefd had, gemelde L. Latrie by den Heer De Graaff rapport bragt, dat in de Pastory en de Kerk meer dan duizend menschen zich verzameld hadden, en hy niet durfde wagen alleen binnen te gaan. -

Dat ik hierop een onderagent naar de stad zond om van dat alles aan den Raad fiscaal rapport te maaken, ten gevolge waarvan zich een detachement Militairen door my vergezeld naar gemelde pastory begaf. -

Dat ik in tegenwoordigheid van L. Latrie en gezegde detachement de menigte aansprak en vermaande tot vermyding van onaangename gevolgen de Pastory te verlaten; waarop my den persoon van Constantien Naar ten antwoord gaf: "dat het kun kerk was, en zy er in blyven konden zo lang $z y$ verkosen. -

Dat ik hierop nogmaals hun ten goede vermaande, echter ziende dat zulks van geen effect was, velden de Militairen het geweer en verjaagde de menigte welke zich voor de plein verzameld hadden. -

Dat wy hierop dadelijk van alle kanten en hoeken met swermen van stenen gesmeten wordende en ziende dat zulks heviger wierd naar mate de omstanders met woorden vermaand wierden; loste de Militairen eenige schoten in de lugt; en nogthans het smyten niet ophoudende, gaf de korporaal van de detachement last om met scherp te schieten naar dien kant waar zulks van daan kwam.

Dat onderwyl de Priester uit de Pastory kwam en aan my vroeg of hy vry konde gaan, waarop ik hem zyde van ja, dat het genoeg was indien hy de Pastory verliet.

Vervolgens aan den Raad fiscaal rapport gedaan zynde door den Stads Chirurgyn, over den persoon van Theod ${ }^{\mathbf{g}}$. Lesire welke met een geweer schot dood geschoten was, wierd my door Zyn EdGestr : gelast het Lyk ter fiscalaat te transporteeren, het welk geschied is."

In het bijgevoegde visum repertum van den stadsgeneesheer A. H. E. Ph. Schuler verklaart deze in tegenwoordigheid van kapitein Van Raders ,in het huis van de Roomsche Katolyk kerk of Pastori in de tweede verdieping in de gaanderij" onderzocht te hebben het lijk van Lesire en bevonden te hebben „het Cranium of Bekkeneel verbryssel, en de hersenen daaruit, veroorzaakt door een schot". Gewond was ook Aldersina slavin van Maria Ignasia Christiaan „met een geschote wond door en door aan de regter onderarm schuins door de articulatie van de Ellebog, veroorzaak door een geweer schot".

Er moet ook nog een verslag van den plaatselijken commandant zijn geweest doch dit heb ik in het $\mathrm{Oud}$ a r c h i e f niet aangetroffen. 
Wel is er ${ }^{1}$ ) een brief van De la Olleria aan den gouverneur van 2 Juni, waarin deze schrijft, volgens de overzetting van Ricardo uit het Spaansch:

\begin{abstract}
„Als Pastoor van deze Katolieke Kerk vind ik my in de noodzakelykheid ter superieure kennis van Uwe Excellentie te brengen de rampspoedige atentaat, hetwelk gister avond om acht uuren ter myne logis naast gemelde kerk heeft plaats gehad; op dat uur wierd my door Lorau de Latry eene missive van de kerkmeesters derzelve overhandigd, waarvan den inhoud luidende was als volgt: (volgt het bekende briefje van 1 Juni). Zoodra als ik dezelve ontving, en de lecture derzelve slechts geeindigd hebbende zonder my tyd van overdenking te geven, wierd ik overvallen met de schoten van geweren door de vengsters van de binnen plaats, waardoor Theodorus Leseau ${ }^{2}$ ) het leven verloor, een vrouw gewond, en de vryheid van den Tempel ter neder getrapt, dit geval veroorzaakte eenen volksbeweging dewelke my blootstelde, slagtoffer te worden, en indien het schandaal en wanorde, geen slegtere gevolgen gehad, zoo is men dit verschuldigd (veroorloof my het te zeggen) aan de voorzigtigheid waarmede ik my gedragen heb, nemende mynen toevlugt terstond naar een ander huis, trachtende aan Uwe Excellenties bevelen zoo als gezegd wierd in gemelde missive te voldoen, als mede om myn persoon in veiligheid te stellen, verlatende en my verwyderende van mynen Ministerie, tot den ontvangst, gelyk ik zulks verwacht, van uwer Excellenties nadere orders,

De Here beware Uwe Excellentie voor vele Iaren".
\end{abstract}

Uit het verhoor op vraagpunten van De la Olleria ${ }^{3}$ ) voor Raden-commissarissen Specht en Meyer blijkt nog, dat hij omstreeks 8 uur, op bezoek zynde bij zekeren Mendisabel een verzoek van „Loran Latre” kreeg om hem een boodschap over te geven, hetgeen echter in de pastorie moest geschieden. Daar gekomen - de pastorie was toen nog niet omringd met een hoop volks, en een detachement militairen zei hij toen niet gezien te hebben ontving hij den brief van de kerkmeesters. Meest vrouwen waren in de pastorie gekomen en een priester, Pablo de Caspe, aan wien hij het briefje ter lezing gaf. De la Olleria was toen in de kerk gegaan en had daar toen priesterlijke handelingen verricht. Hij ontkende, naar buiten gekomen, met den onderschout gesproken te hebben. Wel gaf hij toe, dat de geweerschoten niet zoo kort op het ontvangen van den brief gevolgd waren, en hield slechts vol, dat hij

1) O u d-a rchief, no. 214.

2) Zoo staat het inderdaad in den Spaanschen brief.

s) O u d-a rchief, no. 314 . 
nog geen half uur de brief had ontvangen toen hij door de geweerschoten verrast was ${ }^{\mathbf{1}}$ ).

Den 3den Juni gaf de gouverneur naar aanleiding van des fiskaals brief van denzelfden dag een beschikking, die ook merkwaardig is, om de motiveering van zijn bevoegdheid tot ingrijpen. Van den priester werd daarin gezegd, dat hij had nagelaten , de welgezinde poging van de wettige autoriteiten des lands, ter voorkoming van ongeregeldheden, welke eene daad, hoe wettiglijk en geoorloofd dezelve ook moge wezen, zoude kunnen te weeg brengen, in zoo ver zulks voor hem mogelijk konde zijn, te ondersteunen." Voorts had hij de waarschuwing van den fiskaal in den wind geslagen ,en met minachting behandeld.... door zonder ons welmeenen af te wachten, dat gene ten uitvoer te brengen waartegen hij gewaarschuwd en vermaand was; doch welk evenwel zoude hebben kunnen geschieden en ook zoude geschied zijn na dat de wettigheid daarvan aan ons ware gebleken, in welk geval wij niet zouden hebben nagelaten, des verzocht zijnde, den genen die door ons tot de uitoefening der functien van Roomsch Pastoor alhier was geadmitteerd, daarin te handhaven, bij aldien men ondernomen had hem in dezelve te storen". De pastoor werd ontslagen, omdat hij blijk gegeven had van zijn ongezindheid om met de wettige autoriteiten des lands tot het algemeene welzijn mede werkzaam te zijn, en ,zelfs aanleiding gegeven tot de onaangename gevolgen welke zijne voorbarigheid, aan wederspannigheid grenzende, heeft te weeg gebragt."

De beschikking van den 1sten Juni, aldus gaat de gouverneur voort, aan de kerkmeesters toegezonden behelsde „eeniglijk de suspensie van den Pastoor", en die schorsing is gedaan „krachtens diezelfde magt welke wy op onze verantwoordelijkheid uitgeoefend hebben in de admissie van dien pastoor om de roomsch Catholyke gemeente op dit eiland niet herderloos te laten, niettegenstaande de aanschrijving van hooger hand bij ons toen reeds ontvangen om geene roomsch Catholijke geestelijken, in deze

$\left.{ }^{1}\right)$ Ook De Latry is nog gehoord, maar dit heeft niets nieuws opgeleverd.

2) O u d-a r c hi ef, no. 241. 
kolonie als vaste geestelijken te admitteren dan de zulke die kunnen aantoonen als zoodanig, met voorkennis van het Nederlandsch Gouvernement gezonden te zijn'”. 1)

En wat nu betreft het optreden van de gewapende macht en het sluiten van de kerk: het kerkbestuur had moeten weten hoe te werk te gaan, „om die suspensie gestand te doen", en in hoever het daartoe de sterke hand noodig had. De overheid is verplicht „de sterke hand te bieden aan alle publieke functionarissen in de uitoefening van dat gene hetwelk zij als hunnen pligt beschouwen". Daarom zouden de kerkmeesters verantwoordelijk gesteld worden ,voor al het gene zij in het onderhavig geval, op naam en gezag van het Gouvernement mogten hebben bevolen en doen ten uitvoer brengen, dat echter in onze meer gemelde dispositie van den $1^{\mathrm{e}^{\mathrm{n}}}$ dezer, no. 426 aan hen medegedeeld, niet is uitgedrukt" ${ }^{2}$ ). Maar ook voor het gesloten blijven van de kerk stelde de gouverneur de kerkmeesters aansprakelijk. „De diensten stonden stil zelfs op Pinksteren", schrijft Niewindt verontwaardigd. En terecht. Cantz'laar was het ook, toen op 1sten Pinksterdag, 6 Juni, kapitein Van Raders rapporteerde dat de korporaal die het detachement Roomsche militairen, dien morgen naar de kerk geleid had, meedeelde, dat zij de kerk gesloten hadden gevonden, en dat de koster desgevraagd gezegd had, ,geene order tot het openzetten der kerke te hebben". Met een beroep op zijn taak volgens art. 20 van het Regeeringsreglement, „voor de rigtige uitoefening van den Godsdienst (te) waken", stelde de gouverneur de stukken in handen van den fiskaal, om te onderzoeken in hoever de gouverneur zou kunnen ingrijpen en zorgen „dat geene kerk willekeuriglijk worde gesloten gehouden, waardoor de gemeente van de Godsdienstoefening ontstoken blijft" ${ }^{2}$ ).

Tengevolge van deze opdracht hoorde de fiskaal den custos der R.K. kerk, Bartholomeus Senior. Diens verklaring van 10 Juni doet ook de vraag rijzen of het sluiten dan wel het gesloten blijven van de kerk als de oorzaak

1) Bedoeld is de reeds vermelde aanschrijving, van $11 \mathrm{Juli} 1823$.

2) O u d-a r c h i e f, no. 241. 
van de plaatsgehad hebbende ongeregeldheden moet worden beschouwd ${ }^{\mathbf{1}}$ ). Men leest daarin nl., , dat in den avond van dingsdag den 1 en Juny ll. de kerk door hem naar gewoonte nadat de Rosaria geeindigt en de gemeente uit de kerk was gegaan, omstreeks 7 uren is gesloten geworden. Over het gesloten blijven van de kerk verklaarde Senior, dat hij 2 Juni de sleutels van kerk en pastorie aan den kerkmeester De Graaff wilde geven, maar deze weigerde die aan te nemen, omdat hij geen orders gegeven had, de kerk en pastorie te sluiten. Hoe hij dit rijmde met het briefje aan De la Olleria is niet duidelijk. Den volgenden dag zou Senior op last van Monsanto de kerk op het gewone avonduur, 4 uur, geopend hebben, maar niemand was binnengekomen, waarop hij de kerk weer gesloten had uit vrees voor diefstal. Zaterdag voor Pinksteren had Senior Monsanto gevraagd, of hij de kerk openen moest, maar deze maakte zich ervan af, met te zeggen, dat hij niet de eenige kerkmeester was en stuurde hem naar den gouvernements-secretaris Prince. Deze antwoordde „dat hy de mis konde openen", en in kennis gesteld van dit antwoord, zond Monsanto hem naar De Graaff, die op zijn standpunt bleef staan. Daarop hield Senior de sleutels maar onder zich.

Er is ook een brief van den gouvernements-secretaris Prince aan den gouverneur van 11 Juni $1824^{2}$ ), waarin deze schrijft, dat hij op 1 Juni 's avonds op Pietermaai De Graaff ontmoet had, die tevergeefs getracht had den gouverneur te spreken. De kerkmeester had toen gezegd, dat hij wegens de schorsing van De la Olleria ,zeer angstig was, niet alleen voor zijne personele veiligheid, doordien men die suspencie aan hem zoude toewyten, maar wegens den invloed die de Spaansche Priesters in deze Kolonie op de Roomsche gemeente hadden, waardoor de gemeente zich tegen de suspensie van den Pastoor zoude

$\left.{ }^{1}\right) \mathrm{Oud}-\mathrm{r}$ c h i ef no. 314. Het lijkt mij gewenscht, dat ook het bekende M e m ori a a l van dezen custos Bartholomeus Senior, dat over deze gebeurtenissen wel niet zwijgen zal, en in het bezit der R. K. missie is, hierover wordt openbaar gemaakt.

$\left.{ }^{2}\right) \mathrm{O}$ u d-a r c h i e f, no. 314 , verkeerdelijk gebonden in de brieven van December van dat jaar. 
mogen verzetten, daarbij voegende dat als de Pastoor gesuspenseerd wordt, de kerk dan zoude moeten gesloten worden; Waaropik aanmerkte geene noodzakelijkheid tot het sluiten der Kerke, om reden van des Pastoors suspensie in te zien, uithoofde dat het my wel bekend was, dat vroeger, wanneer de Pastoor afwezig was, de Godsdienstoefening in de roomsche kerk toch onafgebroken voortging." -

Dahlhaus deelt mee ${ }^{1}$ ), dat 11 Juni de kerk weer geopend is. Dat is echter niet gebeurd naar aanleiding van een request van Fournier, De Graaff en Monsanto aan den gouverneur, om de redenen te vragen voor de opschorting der heilige diensten, de suspensie van den pastoor en het verbod aan de overige geestelijken, die zich op het eiland bevonden, om de geestelijke diensten te verrichten. Zulk een adres wordt in het gouvernements-journaal ${ }^{2}$ ) niet vermeld en is bij de ingekomen rekwesten niet te vinden ${ }^{3}$ ). Wel is er een verzoekschrift tegen de kerkmeesters, dat de gouverneur in den Raad van politie bracht maar ter wille van een vormbezwaar daarbuiten behandeling moest blijven.

Eenige dagen later wendde zich de geestelijke Salvador Garcia Ortigosa ook namens Serafin de Sevilla en Benita de Villavitiosa tot den gouverneur met verzoek om hun werkzaamheden, waarin zij reeds zestien dagen ,,gesuspendeerd" waren, weer te mogen uitoefenen ${ }^{4}$ ). Dit verzoek werd door den gouverneur aanstonds met de grootste welwillendheid ontvangen. De gouvernements-secretaris werd door den gouverneur dadelijk persoonlijk naar de kerkmeesters gezonden om het verzoek over te brengen. Prince ontmoette Fournier, die met het plan instemde, en ging daarna door naar de priesters om hun des gouverneurs tevredenheid over hun ijver te kennen te geven, met betuiging, dat het hem ,niet dan zeer aangenaam (kon) zijn in de gelegenheid te wezen om den Godsdienst

\footnotetext{
1) T.a.p., bladz. 53 .

2) O u d-a r c hi ef, no. 241.

s) Id., no. 297.

4) O u d-a rchief, no. 314 .
} 
te bevorderen.” De priesters werden „provisioneel en tot wederopzeggings toegelaten" 1). Den volgenden dag werd Nicolaas de Busto op zijn verzoek aan hen toegevoegd ${ }^{2}$ ), en omdat geen der priesters pastoor wilde zijn, werd als zoodanig benoemd Pablo de Caspe ${ }^{3}$ ), echter zonder bevoegdheid om priesters aan te stellen zonder voorafgaande toestemming van den gouverneur. Eenige dagen later weigerde de gouverneur toelating aan Domingo Maestre en Phelipe Sanchis, omdat ook vergeleken met vroeger, de gemeente nu ,genoegzaam met gekwalificeerde Geestelijken .... . voorzien" was. Op het desbetreffend verzoek van de Kerkmeesters teekende de gouverneur tevens aan: „kan er echter een goede reden bestaan om ook deze toe te laten, stel ik mij desnoods daartegen geen partij $\left.{ }^{4}\right)$. En inderdaad is de gouverneur nog in dezelfde maand op deze weigering teruggekomen.

Ook tot aanvulling van het college der kerkmeesters was het intusschen gekomen. Alexander Meggi en Johan M. Krapf werden aan den gouverneur daartoe voorgedragen, die zich ertoe bepaalde de benoeming ,te houden voor informatie en daarin, voor zoo veel zulks noodig is, te berusten" 5 ).

De la Olleria heeft op des gouverneurs bevel om het eiland te verlaten den 9den geantwoord. Hij verklaarde het zijn plicht als „Katholiek” en als leeraar van den godsdienst om gehoorzaam te zijn aan de bevelen van de wettige overheid, en vroeg een paspoort naar Puerto-Rico ${ }^{6}$ ).

1) De gouverneur zegt in den desbetreffenden brief uitdrukkelijk, dat alleen Olleria was geschorst en ,niet zij .... noch anderen die door ons niet waren geadmitteerd".

2) O u d-a r c hi ef no. 314 .

s) In het doopboek teekende hij aan, dat hij net het ambt van tijdelijk pastoor zich belast had, omdat hij door pater Olleria bij diens vertrek in diens rechten gedelegeerd was. Dahlhaus, t.a.p., blz. 45.

4) O u d-a r c h i e f, no. 314.

s) De gouverneur stelde hen dus niet aan, zooals Dahlhaus, t.a.p., bladz. 53 zegt. Zie O u d-a r c h i e f, nrs. $241,314$.

') De Spaansche brief is te vinden in O u d-a r c h i e f no. 314. Op de vertaling van Ricardo is met de hand van den gouverneur aangeteekend: "dit is een zeer onduidelijk (translaat)". Op 13 Juni kreeg De la Olleria uitstel op zijn verzoek, „onder voorwendsel van geen genoegzame secure gelegenheid naar Porto Rico"' gedaan. 
Op 's Koningsverjaardag, 24 Augustus 1824, viel de onderschout Dittinger door een geweerschot van zekeren A. Rampelenberg. Dahlhaus en Brusse leggen verband tusschen dit misdrijf en Dittingers optreden in den avond van 1 Juni, ik heb echter niet de minste aanwijzing kunnen vinden, die aannemelijk maakt, dat dit verband op iets anders dan overlevering berust. Rampelenberg gaf op dat hij, meenende, dat zijn geweer ongeladen was geweest, schertsenderwijs op Dittinger aangelegd had. Deze had echter twee kogels in de borst. -

Als wij nu nog eens nagelezen hebben wat Brusse en Simons omtrent deze gebeurtenissen vermelden, dan zullen wij moeten bekennen, dat zij ook hier weer er maar op los gefantaseerd hebben, en Cantz'laar groot onrecht aangedaan hebben. Het sluiten van de kerk en de gevolgen daarvan is hem niet toe te rekenen. En wat Dahlhaus betreft, Cantz'laars optreden tegen De la Olleria is, in de lijst van plaats en tijd bezien niet vreemd ${ }^{\mathbf{1}}$ ). Het geeft geen reden hem te verdenken van eenige vooringenomenheid tegen de Roomsche kerk. Integendeel hij was er aanstonds op uit om de herderloosheid der gemeente op te heffen, die in plaats van één vijf ,geadmitteerde" geestelijken kreeg.

De kerkmeesters De Graaf en Monsanto hebben nog onaangename oogenblikken gehad over het geding dat de fiskaal hen dadelijk begon aan te doen over de sluiting van de kerk in naam van den gouverneur, die daartoe geen last gegeven had. Bij hun ontslag kort na Niewindtskomst trachtten zij eerst nog van de kerk borgstelling te verkrijgen voor de schade, die zij door dit proces konden lijden ${ }^{2}$ ).

In dit geding is nog eens zonneklaar gebleken, dat het sluiten van kerk en pastorie zelfs niet stilzwijgend in de „suspensie” van De la Olleria kon opgesloten liggen. De

1) Wel om heel wat minder werd ds. Bosch ter verantwoording geroepen nl. over onaangename woorden, die hij in zijn preek aan het adres van den kapitein der artillerie P. C. Simon zou gesproken hebben.

$\left.{ }^{2}\right)$ Gouvernements-journaal 9 Sept. 1824. O u d-a r c h i e f, no. 241. 
gouverneur meldde den fiskaal voor diens conclusie van repliek uitdrukkelijk, dat hij in den avond van 1 Juni 1825 den kerkmeester De Graaff „op geenerlei wijze .... gelast, aangeraden of te verstaan gegeven (had,) dat hij den Pastoor uit de Pastorie zouden zetten of de kerk sluiten zoude"; de gouverneur had gemeend, dat behalve de geschorste nog een geestelijke aanwezig was, nl. Antonio Dias, 30 Mei 1822 als assistent van den pastoor toegelaten, en daarmee zou het sluiten van de kerk moeilijk te rijmen zijn geweest. ${ }^{\mathbf{1}}$ )

Een half jaar later volgde het vonnis tegen de kerkmeesters.Tegen Monsanto werd de eisch ontzegd, daar hij geheel onschuldig was aan het gebeurde, als zijnde hij bevoegd zijn medekerkmeester te gelooven. Ook De Graaff kwam er boven alle verwachting goed af. Hij werd schuldig geacht aan ,overschrijding der bevelen van het Gouvernement". Voor niet bewezen werd gehouden, dat hij te kwader trouw zou hebben gehandeld; hij had verzuimd zich bekend te maken met de bedoeling der gouvernementsorders, en die, zelfs volgens de uitlegging door hem daaraan gegeven, op een onbezonnen wijze uitgevoerd. En wat de straf voor dit verzuim betreft, werd overwogen, dat de kosten, die deze procedures hem hadden veroorzaakt „op zich zelve reeds eene genoegzame som belopen om als poene te worden opgelegd." Er werden soms wonderlijke vonnissen gestreken onder het oud-Hollandsche recht, maar dit was toch gelukkig ook het juridisch gevoel van den fiskaal te machtig, en de gouverneur vond het een zonderlinge straf, niet evenredig aan de schuld. Toch schijnt De Graaff er nog last genoeg van gehad te hebben. De Curaçaosche courant van 31 Mei 1828 bevat een brief van den Staatsraad Stratenus van 25 Oct. 1827 aan D. de Graaff, apotheker te Curaçao, in antwoord op diens verzoekschrift aan den Koning. Daarin wordt gezegd, dat de zaak, waarin 20 Mei 1825 vonnis is gewezen ,geen onderwerp van onderzoek bij Zijne Majesteit worden kan; doch dat de blaam, welke de rekestrant veronderstelt, dat door

1) Gouvernements-journaal 12 October 1824. O u d-a r c h i e f, id. 